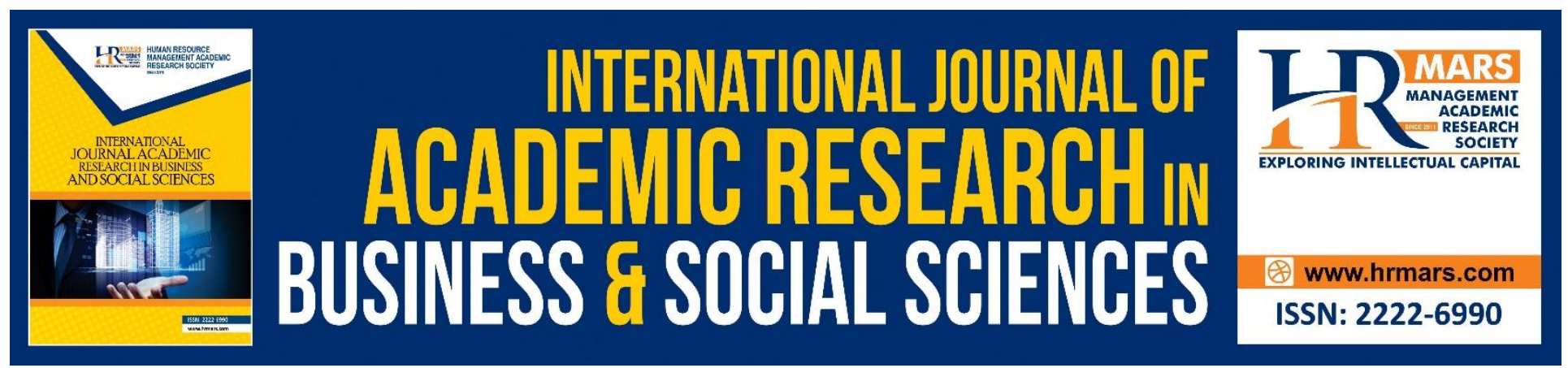

\title{
Shariah Governance Practices and Regulatory Problems of Islamic Insurance Companies in Bangladesh
}

\author{
Md. Kausar Alam, Suhaimi Ab Rahman, Md. Shamim Hossain and \\ Sharif Hosen
}

To Link this Article: http://dx.doi.org/10.6007/IJARBSS/v9-i1/5368

DOI: $\quad 10.6007 /$ IJARBSS/v9-i1/5368

Received: 22 Dec 2018, Revised: 17 Jan 2019, Accepted: 29 Jan 2019

Published Online: 02 Feb 2019

In-Text Citation: (Alam, Rahman, Hossain, \& Hosen, 2019)

To Cite this Article: Alam, M. K., Rahman, S. A., Hossain, M. S., \& Hosen, S. (2019). Shariah Governance Practices and Regulatory Problems of Islamic Insurance Companies in Bangladesh. International Journal of Academic Research in Business and Social Sciences, 9(109-124).

Copyright: (C) 2019 The Author(s)

Published by Human Resource Management Academic Research Society (www.hrmars.com)

This article is published under the Creative Commons Attribution (CC BY 4.0) license. Anyone may reproduce, distribute, translate and create derivative works of this article (for both commercial and non-commercial purposes), subject to full attribution to the original publication and authors. The full terms of this license may be seen

at: http://creativecommons.org/licences/by/4.0/legalcode

Vol. 9, No. 1, 2019, Pg. 109 - 124

http://hrmars.com/index.php/pages/detail/IJARBSS

JOURNAL HOMEPAGE

Full Terms \& Conditions of access and use can be found at http://hrmars.com/index.php/pages/detail/publication-ethics 


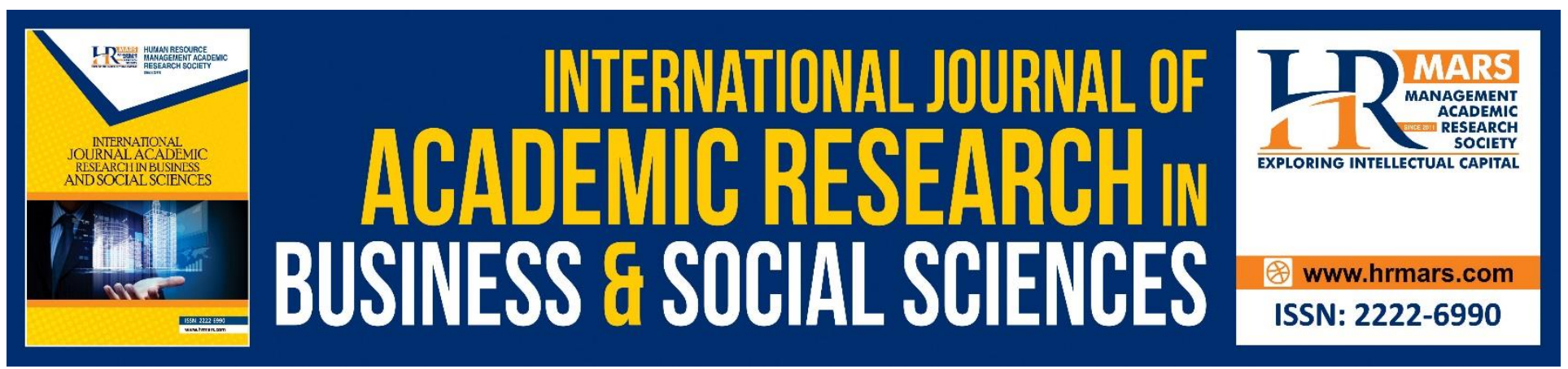

\title{
Shariah Governance Practices and Regulatory Problems of Islamic Insurance Companies in Bangladesh
}

\section{Md. Kausar Alam ${ }^{*}$, Suhaimi Ab Rahman², Md. Shamim Hossain ${ }^{3}$ and Sharif Hosen ${ }^{4}$}

$1 \& 2$ Faculty of Economics and Management, Universiti Putra Malaysia, Serdang, Malaysia,

${ }^{3}$ Department of Business Administration, Manarat International University, Dhaka, Bangladesh and

${ }^{4}$ Faculty of Educational Studies, Universiti Putra Malaysia, Serdang, Malaysia

${ }^{*}$ Correspondent Author's Email: kausarflorence@gmail.com

\begin{abstract}
This paper aims to explore the current practices and problems in the Shariah governance framework of Islamic insurance in Bangladesh. The study reveals that the governance system of Islamic insurance companies in Bangladesh is largely based on voluntary initiatives by itself and there is an absence of full-fledged Shariah governance framework. All Islamic insurance companies in Bangladesh have their own SSB who performs the Shariah audits and review activities. Based on the critical review, it provides some suggestions for the improvement of the Shariah governance framework of Islamic insurance. In order to improve the Shariah governance system of Islamic insurance companies, Bangladesh government should enact a law for its operations and rulings. Moreover, the Insurance Development and Regulatory Authority of Bangladesh (IDRA) should improve its guidelines for Islamic insurance operations to comply with Shariah principles and may recognize the Central Shariah Council for Islamic Insurance of Bangladesh (CSCIIB) so that, they can supervise and monitor the overall activities of Islamic insurance companies in Bangladesh.
\end{abstract}

Keywords: Islamic Insurance, Shariah Governance, Shariah Governance Framework.

\section{Introduction}

The improvement and growth of a country largely depend on the financial sector's roles (Ahmad and Malik, 2009; Hosen et al., 2018). Insurance companies perform a key role and also an imperative part and parcel of economic and financial systems. Currently, 43 insurance companies are operating in Bangladesh and their businesses do not improve highly in annually and they are growing their profits at BDT 400-500 crore more or less yearly (Sarwar, 2016). The first full-fledged Islamic insurance company namely 'Islami Insurance Bangladesh Ltd' was established on 12 December 1999 (Kalil, 
2011) and in 2000, 'Fareast Islami life insurance Co. Ltd.' introduced their business in Bangladesh as a first Shariah based Life Insurance Company. Currently, most of the insurance companies in Bangladesh have separate Islamic insurance wing to meet the continuous customers' demands.

The main objective of this paper is to review the current Shariah Governance (SG) of Islamic insurance companies of Bangladesh. In Bangladesh, Islamic insurance companies have faced legal and regulatory problems in governing their activities (Sarwar, 2016). Due to the lack of a legal and regulatory framework, Islamic insurance companies are losing a huge amount of profit and unable to use their capital and lagging behind (Kalil, 2011). Few studies have been done in regards to the SG of Islamic insurance and most of the cases the problems the SG structure was unexplored. This paper points out the problems related to the Shariah Governance Framework (SGF) of Islamic insurance and provides few suggestions. Therefore, this paper analyzes the development history of Bangladesh Islamic insurance, the literature of SG systems of Islamic insurance, legal and regulatory bodies of Islamic insurance in Bangladesh, current practices of SG within the organizations, obstacles, and recommendations related with the regulatory and SG perspectives. The paper highlights that the Islamic finance industry are facing problems in relation to its operations and functioning. The diversified practices create confusions among the customers concerning the practices, image and Shariah resolutions. So, the government and other stakeholders should come out urgently with a comprehensive SGF to improve the quality of Shariah compliance, minimize the Shariah resolutions, and for a homogeneous practices as well as for further improvement of Islamic insurance.

\section{Development of Islamic Insurance in Bangladesh}

To fulfill the demand of Muslim people in Bangladesh during 1999 Islamic insurance company started its journey in compliance with Shariah principles. Islamic insurance company has made viable position in the insurance market competing with the conventional insurance companies. Nowadays, Islamic insurance is one of the important parts of Bangladeshi economy and fast-growing sector.

Table 1: Size and growth of life insurance

\begin{tabular}{|c|c|c|c|c|c|}
\hline \multirow[t]{2}{*}{ Category } & \multicolumn{2}{|c|}{ Gross premium } & \multicolumn{2}{|c|}{ Market share } & \multirow{2}{*}{$\begin{array}{l}\text { Growth } \\
\text { rate (\%) }\end{array}$} \\
\hline & $\begin{array}{c}2009- \\
2010\end{array}$ & $\begin{array}{c}2011- \\
2012\end{array}$ & $\begin{array}{c}2009- \\
2010(\%)\end{array}$ & $\begin{array}{c}2011- \\
2012(\%)\end{array}$ & \\
\hline \multicolumn{6}{|c|}{ BDT million } \\
\hline $\begin{array}{c}\text { Islamic } \\
\text { Insurance }\end{array}$ & 8637.59 & 5669.30 & 33.02 & 25.95 & -34.36 \\
\hline Insurance & $17,520.09$ & $16,178.85$ & 66.98 & 74.05 & -7.66 \\
\hline Total & $26,157.68$ & $21,848.14$ & & & \\
\hline
\end{tabular}

Source: Ali (2016) 
INTERNATIONAL JOURNAL OF ACADEMIC RESEARCH IN BUSINESS AND SOCIAL SCIENCES

Vol. 9, No. 1, Jan, 2019, E-ISSN: 2222-6990 @ 2019 HRMARS

Table 2: Size and growth of non-life insurance

\begin{tabular}{|c|c|c|c|c|c|}
\hline \multirow[t]{2}{*}{ Category } & \multicolumn{2}{|c|}{ Gross premium } & \multicolumn{2}{|c|}{ Market share } & \multirow{2}{*}{$\begin{array}{l}\text { Growth rate } \\
\text { (\%) }\end{array}$} \\
\hline & $\begin{array}{l}2009- \\
2010\end{array}$ & $\begin{array}{l}2011- \\
2012\end{array}$ & $\begin{array}{l}\text { 2009-2010 } \\
(\%)\end{array}$ & $\begin{array}{l}\text { 2011-2012 } \\
\text { (\%) }\end{array}$ & \\
\hline $\begin{array}{l}\text { Islamic } \\
\text { Insurance }\end{array}$ & 1185.18 & 2326.40 & 5.19 & 4.55 & 96.29 \\
\hline Insurance & $21,659.95$ & $48,769.80$ & 94.81 & 95.45 & 125.16 \\
\hline Total & $22,845.13$ & $51,096.21$ & & & \\
\hline
\end{tabular}

Source: Ali (2016)

Government and the Islamic insurance companies have taken some initiatives for the development of the industry to increase people confidence. However, the legal and regulatory development were not improvised parallel with the development of Islamic insurance industry. As a result, Islamic insurance companies are facing problems in conducting their businesses due to the absence of comprehensive SG though they have the separate Shariah supervisory board. At this moment, in Bangladesh, 8 full-fledged Islamic insurance companies and 13 Islamic insurance windows are conducting their business (TJCSCIIB, 2012; ARIIBL, 2012; Sarwar, 2016). More so, every Islamic insurance windows of conventional insurance companies also have their own SSB to monitor Shariah principles of Islamic insurance business activities.

As a Muslim majority country, Bangladeshi people are usually religious minded, costumes to follow the Shariah rules in their daily lives and try to avoid the haram in their financial and economic lives (Miah, 1992). If Islamic insurance companies are transparent and follow the Shariah rules in their business activities, general public maycavoid the conventional insurance (Sarwar, 2016). In this regard, the Fareast life insurance company is one of the novel examples for the other Islamic insurance companies in the development of Islamic insurance business and growth in the country (Kalil, 2011). If the government introduces a robust and sound SGF for the development of Islamic insurance, its growth as well as acceptance may be increased in the economy.

\section{Shariah Governance}

Governance is a system of guiding, monitoring and controlling institutions and organizations (Hasan, 2008). In accordance with World Bank, governance is stimulating justice, transferability, and responsibility. International Financial Service Board (IFSB) in their standard 3 (2006) defined Islamic Financial Institutions (IFIS) corporate governance, a set of connection between management, the board of directors, shareholders of a company which gives the structure through which the objectives of the company are predetermined; the way of achieving the goals and monitoring performance are determined. Ginena and Hamid (2015) defined SG as a comprehensive system that executes how Islamic Financial Institutions obey the Shariah rules in their business activities and contacts.

A well-organized SGF can build the integrity of Islamic financial institutions in terms of its responsibility and credibility (Hasan, 2008). Besides, Shariah compliance is one of the main 
components that makes Islamic corporate governance very inimitable. Along with roles of board of directors (BOD), SSB in an Islamic insurance has also significant roles to monitor the Shariah compliance of business transactions. One of the major responsibilities of SSB has is to develop and review new product and services to assure the Shariah compliance and also the post ante roles (Bank Negara Malaysia, 2010; IFSB, 2009; Nathan and Ribière, 2007; Abdullah and Rahman, 2017).

In the global markets of SG, different models are existing in the practice of different jurisdictions (Wardhany and Arshad, 2012). In practice, Malaysia has their centralized SGF but in the perspective of Bangladesh, there is a central Shariah supervisory board namely CSCIIB for Islamic insurance companies which is formed by the initiatives of Islamic insurance as an unauthorized body of government. In the centralized practices, central Shariah supervisory board is liable for the whole Shariah compliance matters and validate the Islamic products. The aim of central Shariah supervisory board is to reduce the differences of explanations, conflicts and ensure harmonization and uniformity of Shariah implementations within the practices and to promote good governance within the industry. In centralized SG model, there are two types namely, one-tier and two-tier SGF. In one-tier there is one centralized Shariah supervisory board and in two-tier there are two SSBs. The two SSB in the two-tier are central monitoring body and individual SSB at the institutional level with complying with the rules of central authority.

In this model both SSB have set the standards for SG and any Shariah related matters associated with the operations of Islamic insurance. In contrast, the decentralized model is based on the one SSB in the institutional level to ensure the Shariah compliance in the functions of Islamic insurance. In Bangladesh, the decentralized model is practicing by the Islamic insurance companies. However, this model has been criticized for multiple sitting of SSB in the different Shariah supervisory boards at the same time and creates the conflict of interest. More so, there is no specific guideline for Shariah compliance and to solve the conflicting issues among the various stakeholders.

Figure 2.6: Shariah Governance and Supervision

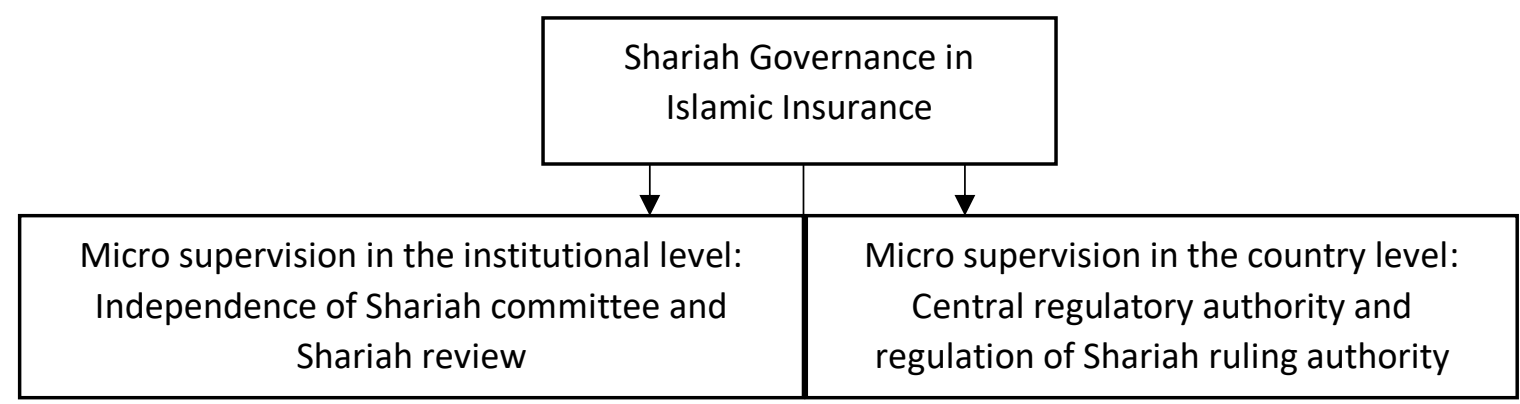

Shariah Compliance

Implementation of the Shariah principles assures that the activities of Islamic insurance are in compliance with Shariah and protect the interest of all stakeholders, beneficiary parties and customers related with Islamic insurance companies. Therefore, it is important for Islamic insurance 
INTERNATIONAL JOURNAL OF ACADEMIC RESEARCH IN BUSINESS AND SOCIAL SCIENCES Vol. 9, No. 1, Jan, 2019, E-ISSN: 2222-6990@ 2019 HRMARS

companies to have a sound Shariah guidelines and standards. These must be monitored by the Shariah supervisory Board, management, and regulatory authority. The SSB should be appointed by respected Islamic insurance companies and the roles and responsibilities of SSB are to supervise, monitor the business activities in ex-ante and post-ante basis in accordance with Shariah guidelines.

\section{Shariah Governance Framework in Islamic Insurance}

The SGF grounded on the epistemology of tawhid and shura for each level of institutions that describes the roles and functions, goals and principles of Shariah (Choudhury and Hoque, 2004). In all average, Choudhury and Haque (2004), Nienhaus (2007), Abdul Rahim (1998) and Banaga et al. (1994) mind to accomplish that a conceptual framework of Islamic corporate governance should take the explanation of the epistemology of tawhid and Shuratic process, the concept of khalifah, social justice, responsibility, monitoring conditions of Islamic Shariah, general banking rules and regulations and the values of Islamic ethics.

There are four principles and components in Islamic corporate governance which include the principle of tawhid through the harmony of knowledge via collaborative, integrative, and evolutional procedure to the interrelating environment features, the principles of justice, the principles of productive arrangement of properties in social and the principles of monetary accomplishments and recursive intention among the overhead point. All of these principles are adorned in accordance with the rules of Shariah derived from Al-Quran and Sunnah and also considered as the key elements of Islamic corporate governance which maintain the principles of social justice and make the Islamic institution as market driven (Choudury and Hoque, 2004). The principle of tawhid originates from the concept of vicegerency (Khilafah), faith (Amanah), and fairness (aladl wal Ihsan). In this aspects, the stakeholders as a representative of Allah have a fiduciary duty to preserve the principles of dissemination fairness through the Shuratic procedure. Chapra, (1992) describes the practice of shura as a compulsion rather than an option. The components of shura illustrate an inclusive participation of all stakeholders in the decision-making process of the institution directly and indirectly.

Abdul Rahim (1998) revealed the Islamic corporate governance as a combination of Islamic Shariah and Islamic moral principles and emphasized that the key components of Islamic corporate governance are the institution of shura, hisbah, and religious audit. The institution of shura is a mixture of BOD, management, shareholders, customers, employees, and other related parties who may ensure in the effective decision-making system that may affect the institution. Besides, the institution of hisbah and regulatory auditor play an important role in observing and monitoring the functions of corporate governance from the viewpoint of ethics and regulation, while the SSB provides the Shariah advisory and supervisory services in Shariah ruling and monitoring on the basis of Islamic principles. Though little has been discussed regarding the corporate governance of Tawhid epistemological methodology (Hasan, 2009), all the Islamic scholars or Muslim solicitors agree on the tawhid concept as a metaphysical pillar of Islamic finance (for example, Mannan, 1970; Siddiqi, 1978; Kahf, 1978; Ahmad, 1980; Naqvi, 1981; Al-Sadr, 1982; Taleghani, 1983; Choudhury and Malik, 1992). In this case, Choudhury and Hoque, (2004) deliberate the basic Islamic epistemology of Tawhid on their corporate governance model. Tawhid is the base of Islamic belief (Al-Faruqi, 1982) and the 
corporate governance system also derives from the perception of belief. That's why the base of Islamic corporate governance shall be the principles of tawhid and all the parties related to the institution are responsible and accountable to Allah.

The tawhid and shura based tactic describes the epistemological basis of Islamic corporate governance which seems to be unclear and confusing to adopt and implement in the current conventional practices of corporate governance (Hasan, 2009). In ascertaining the Shariah in the corporation, the SSB plays a significant role in monitoring and ensuring the Shariah rules and regulations within the activities of the organization. Besides, the shareholders can play an important role by participating in the decision-making process and the policy making of the institution to protect the rights and interest of all stakeholders rather than maximizing the institution's profit. The other stakeholders, as well as the community perform their roles to provide joint collaboration and to safeguard the interest of as a whole and to motivate for the social welfare. All of the procedures are performed through maintaining the principles of justice to accomplish the ultimate objective of the Islamic corporate governance accompanying the private and social goals (Choudury and Hoque, 2004).

IFSB-9 (2009) has defined SG system as "a set of institutional and organizational structures and process through which the Islamic financial institutions ensure that there is effective independent oversight of Shariah compliance over the issuance of relevant Shariah pronouncements, dissemination of information, and an internal Shariah compliance review". This framework has incorporated the objectives, strategical issues, economic incentives and traditional rules and regulations of the institutions. The body of shura is an executing body formed by the board of directors, management, shareholders, employees, and customers might assure the efficiency of the organizations and influence in the decision making of the corporation.

Moreover, it's a large challenge for the scholars how to solve this problem by maintaining these rules and regulations of Islamic Shariah. Generally, a sound SG system is a combination of dual monitoring namely ex-ante and ex-post procedure. Before introducing a new product SSB members have to check the Shariah issues and compliance is known as ex-ante procedure (NuHtay, S. N., and Salman, S. A., 2013). After performing the Islamic insurance activities SSB members must review and audit the whole activities in accordance with Shariah principles that are called ex-post monitoring. The organization namely hisbah and the Islamic auditor play their role from the ethical and supervisory perspective in monitoring the corporate activities of an Islamic insurance company.

\section{Monitoring and Supervising Bodies of Islamic Insurance}

To monitor and govern any business industry in any country, government rules and regulations and its implementation play an important role for the development as well as ensuring the accountability of the industry. In Bangladesh, conventional and Islamic insurance companies are monitored and controlled under a single act. Before the independence, the Insurance Act 1938 has played a significant for the insurance company. After independence, Bangladesh government made the amendment in the Insurance Act 1938 in an order namely Insurance Order 1972. Rather than this, 
INTERNATIONAL JOURNAL OF ACADEMIC RESEARCH IN BUSINESS AND SOCIAL SCIENCES

Vol. 9, No. 1, Jan, 2019, E-ISSN: 2222-6990 (C) 2019 HRMARS

Bangladesh insurance company act was amended as The Insurance Corporations Act, 1973, Insurance Amendment Ordinance of 1984 and the Insurance Act, 2010. To monitor the Islamic insurance, the government did not enact any separate law for its ruling and did not disclose a SG guideline to implement the Shariah principles.

Figure: The monitoring bodies for insurance companies in Bangladesh Source: Hassan, Ullah and Khanam (2017). (Modified)

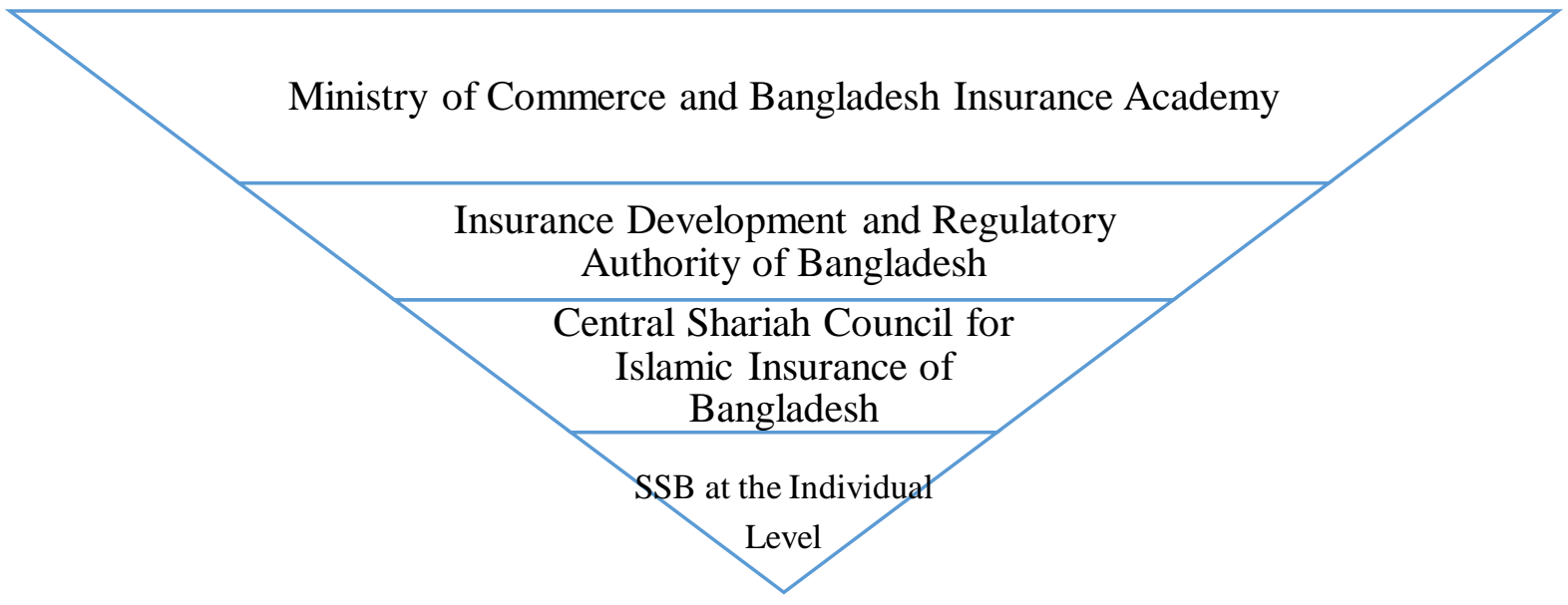

In Bangladesh, Islamic insurance has been defined in the Insurance Act 2010; however, in regulating and monitoring the Islamic insurance, no regulation has been introduced so far. Experts of Shariah must come up with their new contemporary ideas so that they can easily differentiate the compliance and noncompliance of Shariah. An appropriate risk-based well-defined framework would be appropriate for the SSB to identify the possible Islamic insurance path. Insurance Act 2010 in Bangladesh allows the traditional insurance companies to operate on Islamic insurance windows; however, traditional non-life insurance companies are not allowed to open new Islamic insurance windows.

\section{Ministry of Commerce and Bangladesh Insurance Academy}

Both Islamic and non-Islamic Insurance companies are regulated by the Ministry of Commerce in Bangladesh and training and research operations are operated under the body of Bangladesh Insurance Academy. The operation of this academy was started in 1973 under over the government regulation. It sets some objectives to achieve goals: (i) to arrange professional training in insurance; (ii) to do research on the insurance industry; (iii) to execute in-service training for both public and private sector insurance companies; (iv) to issue research works and books on insurance; (v) to launch and uphold close contact with local and international counterparts. In Bangladesh, the ministry of commerce is sole regulatory authority for insurance companies (Chowdhury, 2014). The main role of this organization is to create professional insurers in Bangladesh. In this case, the role and responsibility of this authority are not clear in the perspective of SG. 


\section{Insurance Development and Regulatory Authority of Bangladesh}

Insurance Development and Regulatory Authority of Bangladesh (IDRA) is the only government body for developing and regulating the insurance sector of Bangladesh since 2010 and support the regulatory framework for the insurance industry. Two new laws were launched on 18 March 2010 namely Insurance Act 2010 and IDRA Act 2010. Now, 77 insurance companies started operations in the county and monitored by IDRA within sound rules and regulations. The IDRA Act 2010 has been approved the path for better rules of the sector by minimizing business risk and by coordinating local and international insurance laws for economic development of Bangladesh. The attempts of IDRA are to protect the interest of insurance policyholders, receivers and safeguarding the sustainability of the insurance sector. IDRA also regulate two state-owned company namely Sadharah Bima Corporation (SBC) and Jiban Bima Corporation (JBC) and has so far undertaken different steps and measures to reorganize the insurance sector and bring in much-required discipline and comprehensive business principles in the industry.

\section{Central Shariah Council for Islamic Insurance of Bangladesh}

The development of Islamic insurance industry has a relationship with Islamic Banking Industry. In Bangladesh, Islamic insurance industry operate itself in the many prestigious positions currently, which have 8 full-fledged Islamic insurance companies and 13 others providing Islamic insurance service through Islamic windows (Kalil, 2011; TJCSCIIB, 2012; and Khan, Rahman, Yusoff, \& Nor, 2016). SSB members, owners and promoters all of the Islamic insurance companies agreed in 2002 (ARCSCIIB, 2010) and established the Central Shariah Council for Islamic Insurance of Bangladesh (CSCIIB) as a private body to provide and develop uniform Islamic services by minimizing the discrepancies which registered in 2008 (ARCSCIIB, 2011).

[[][

The major objectives and functions of CSCIIB is to achieve complete Shariah compliant insurances, include suggesting the Insurance Development \& Regulatory Authority Bangladesh, proposing necessary measurement and implementing full Shariah rules in all companies, providing training to employees and officers, developing new products, arrange conferences and instigatingseminars and instigate welfare activities through the companies (Khan et al., 2016). The CSCIIB provides the advisory service for the development of this industry but its legal attributions are not recognized by the ministry of commerce and insurance development academy. That is why Islamic insurance companies are not bound to follow their suggestions and rules and regulations.

\section{SSB at the Individual level of Islamic Insurance Company}

Both Islamic insurance company and conventional insurance company with Islamic windows have a SSB to monitor the business activities in compliance with Shariah (Khan et al., 2016). In Bangladesh, Islamic insurance companies are similar to Islamic Bank which has been facing a shortage of Shariah scholars. Conventional Insurance Act 1938 (modified in 2010) numerously affects the SG because of no separated law for Islamic insurance. Though several steps were taken in 2007 no significant outcome has been introduced. More so, new insurance act 2010 provides the guidelines of investment assets rather than Shariah guidelines (Hassan et al., 2017). SSB provides their suggestions 
INTERNATIONAL JOURNAL OF ACADEMIC RESEARCH IN BUSINESS AND SOCIAL SCIENCES

Vol. 9, No. 1, Jan, 2019, E-ISSN: 2222-6990 (C) 2019 HRMARS

in the pre and post-implementation activities of Islamic insurance company. Their role is not clear from the perspective of SG supervision and monitoring the insurance activities.

\section{Shariah Governance Practices in Islamic Insurance Company}

Without any Shariah guidelines from regulatory authorities, Islamic insurance companies run their business in accordance with their individual Shariah Supervisory Board. Similar to the Islamic banks, all the Islamic insurance companies also have Shariah Supervisory Boards except three in which case we don't find any information on the websites of the companies. In one insurance company, regarding with Shariah council, it has an extra layer of Shariah authorities named as Shariah executive committee. This is very unique in the perspective of the world practice. This two-tier Shariah committee monitors the Shariah principles in conducting business activities. Individual Shariah board of Islamic insurance companies performs the audit and review activities by the Shariah department officers.

On an average, most of the SSB members of Islamic insurance companies have Islamic educational background except for Fareast and Prime Life Insurance companies (Hassan et al., 2017). Hassan et al. (2017) also reveal that the five Islamic insurance companies (those have the information of SSB), SSBs of three companies consists of members from management. Regarding the activities, four companies disclosed information on a number of meetings they met during 2015 and only Prime Islami Life Insurance Company provided information on the number of branches audited. However, they only audited $14.19 \%$ (64 out of 451 ) of the branches of the company. Overall, SG system of the insurance companies appears to be inadequate in the aspect of comprehensiveness and standardization to ensure the Shariah compliance in all operations (Hassan et al., 2017). Companies didn't disclose the Shariah violation amount and the SSB report in their annual report. In Bangladesh for Islamic banks and Islamic insurance, we have two separate central Shariah committee body for monitoring the activities of respected sectors which is also another distinctive practice rather than the other countries of the world. But the CSCIIB provides the advisory service regarding the Shariah issues, and monitor the Shariah activities.

\section{Regulatory Problems of Islamic Insurance}

Despite having seen double-digit growth since 2010, Islamic insurance industry still suffers from a lack of perception in supposedly vibrant markets and is still performing at what is considered to be lackluster levels. In governing the activities of Islamic insurance, Bangladesh has an absence of a comprehensive SGF. There is no specific guideline from the regulatory authorities to conduct the business in accordance with Shariah, Shariah audit, Shariah review, and Shariah risk. Due to the lack of research among the Islamic insurance, there is a lack of Shariah-based products and talents.

Such variances make it difficult for Islamic insurance operators to function across regions and also lead to confusion for customers and multinational insurers. Operators of Islamic insurance pay high attention to continue efforts to develop knowledge, skills, and expertise of their employees through various programs such as training, seminars and conferences. Mostly in the areas of marketing and information system were also implemented by the Islamic insurance operator as part of their efforts 
INTERNATIONAL JOURNAL OF ACADEMIC RESEARCH IN BUSINESS AND SOCIAL SCIENCES Vol. 9, No. 1, Jan, 2019, E-ISSN: 2222-6990 @ 2019 HRMARS

to enhance effectiveness and efficiency (Sarwar, 2016). Around the world, the huge number of problems is developed in the Islamic insurance (Bekkin, 2007). Similarly, this scenario is also same in Bangladesh (ARTIIL, 2012).

A minimal number of the regulatory framework is developed towards the Islamic insurance sector in Bangladesh. In this sector, many government policies and government intervention can be proved as beneficiary for its growth and development (Sarwar, 2016). Following the Act, rules and regulations of conventional insurance, Islamic insurance companies are facing huge problems such as the conflict in the Shariah resolutions and scholars, operating systems, institutional image, product development, utilization of funds, and customers believe. The previous government didn't prioritize for promulgation of Islamic insurance; however, the present government is keen to frame its policies in line with general principles and not similar to reconsider the proposed Islamic insurance Act (Ali, 2008). The consultants who are working with the Islamic Development Bank also failed to develop new rules, and regulations for Islamic insurance industries. Lack of expertise is one of the great problems (Ali, 2008); to introduce new and appropriate rules and regulation for Islamic insurance industry, hence, Islamic insurance plays in the different level playing field.

In 2000, Islamic insurance companies of Bangladesh get the license under the old Insurance Insurance Act, 1938 which isn't applicable perfectly on Islamic insurance (Khan, 2010). Though Islamic insurance companies are established on the basis of Shariah principles (Foster, 2007), traditional insurance companies are established on basis of traditional regulations (Schwarcz and Schwarcz, 2014). The absence of a comprehensive SGF has stifled the Islamic insurance industry. Insurance companies of Bangladesh don't provide enough formal training for the employees. They are given a small number of training about insurance (Ullah, 2013). The Islamic insurance companies of Bangladesh don't have any training institution though Bangladesh Insurance Academy provides training on conducting Islamic insurance and there is very few comprehensive training on the Islamic insurance systems and research (Khalid, 2007).

\section{Recommendations for the Enhancement of Shariah Governance Framework}

In order to stop a stagnation of growth within a sector being ultimately brimming with high potentiality, we need to take a proper step at the basic position of the Islamic insurance industry, which comes from a micro and macro perspective and needs to be accomplished to alleviate these problems. Operators are highly concentred on increased variances in regulatory regimes around the jurisdictions though most operators are taking this as a positive development.

Islamic insurance has to perform their activities from in compliance with Islamic law. From contracts to audit they have to follow the Shariah rules and free from interest, gambling, fake, pressure, higher possibility of doubt. The insurance act provides the appointment guidelines of Shariah consultants, still, the government fails to form the regulatory body for the Islamic insurance companies. Due to the slow process, attached with the melancholy dominant political situation are affecting them in much more in the development of a sound and comprehensive SGF for the development of Islamic insurance industry. A sound and complete SGF improves the customer confidence and also allows the Islamic insurance companies to develop new initiatives within the Shariah. 
To solve this problem, government should come out with a comprehensive SGF for the Islamic insurance companies to assure the Shariah compliance in their business activities. For this growing industry government and the regulators should come out special initiatives such as more Shariah based product, comprehend and standard SG guideline (Ali, 2008). In this case, the government can consider the cross-border experiences and practices to prepare the Shariah guidelines. Islamic banks and Islamic insurance are regulated by the central bank of Malaysia by the separate Islamic insurance act 1994 and monitored by a centralized Shariah body (Abu-Hussin et al., 2014). Now, Malaysia has become a leading country for Islamic insurance company after announcing the separate act and guidelines (Yazid et al., 2012).

The government may set up a central monitoring body for the Islamic insurance industries besides the regulatory body who will help to execute audit and review the program, guide in Shariah related issues, fine, punishment, checking the fraud and illegal activities. For the improvement of the quality of employees, operators may establish a training center or arrange training regarding contemporary issues. According to Sarwar (2016) survey, Islamic insurance sector has a better possibility in Bangladesh to grow up its business and the regulatory authority and the organizations should take proper steps to the development of this industry. In the end, the regulatory body and Bangladesh government can implement the Islamic insurance standards of The International Financial Service Board (IFSB) and develop comprehensive SGF for better monitoring, accountability, and more Shariah compliance.

\section{Conclusion}

A sound SGF is beneficial for the development of the Islamic insurance company and is essential to implement the Shariah principles in their overall activities. In Bangladesh, still, there is an absence of separate rules and regulatory body to monitor and regulate the Islamic insurance (ARPILIL, 2012). The paper has beneficial contributions towards the Islamic insurance and the IDRA. Firstly, the study describes the difference problems regarding the SG practices and suggest that why the Islamic insurance company need a comprehensive SGF. Secondly, the IDRA can revise the current guidelines, international standards and practices to develop a homogeneous and comprehensive SGF for the development of current practices and shariah compliance quality. Finally, the paper gives an additional idea concerning the current SG environment and the supervisory system of SSB in relation to Islamic insurance towards the existing literature.

To solve the problems the future researchers can take initiatives to develop a comprehensive SGF. Moreover, the government should take the initial step to make a separate law and dynamic system to improve the growth of this industry. The development of Islamic insurance industry is an immense and a certain look. To motivate current market players, to attract prospective investors, to ensure the accountability and improve the quality of Shariah compliance, the government needs to develop a sound regulatory and legal regulatory framework for the Islamic Islamic insurance industry in which all stakeholders roles include clearly. If the government and other respected authorities take the steps to solve the problem Bangladesh will be the role model for the Muslim countries in Islamic insurance business. 
INTERNATIONAL JOURNAL OF ACADEMIC RESEARCH IN BUSINESS AND SOCIAL SCIENCES

Vol. 9, No. 1, Jan, 2019, E-ISSN: 2222-6990 (C) 2019 HRMARS

\section{References}

Abdullah, M. F., \& Rahman, A. A. (2017). Shari'ah Governance of Islamic Banks in Bangladesh Issues and Challenges. Journal of Islamic Economics, Banking and Finance,13(3), 82-94.

Abdul Rahim, A. R. (1998). Issues in corporate accountability and governance: An Islamic perspective. The Amercian Journal of Islamic Social Science, 15(1), 55-69.

Abu-Hussin, M. F., Muhamad, N. H. N., \& Hussin, M. Y. M. (2014). takaful (Islamic Insurance) Industry in Malaysia and the Arab Gulf States: challenges and future direction. Asian Social Science, 10(21), 26-34. doi:10.5539/ass.v10n21p26.

Ahmad, K. (1980). "Economic Development in an Islamic Framework", in Ahmad, K. (Ed.), Studies in Islamic Economic (pp. 171-190). Leicester: Islamic Foundation.

Ahmad, E., \& Malik, A. (2009). Financial sector development and economic growth: An empirical analysis of developing countries. Journal of economic cooperation and development, 30(1), 1740.

Al-Faruqi, I. R. (1982). Al-Tawhid: Its Implications for Thought and Life. Herndon, Virginia, The International Institute of Islamic Thought.

Al-Sadr, M. B. (1982). Iqtisaduna (Transl.), Volume 1 and 2. Tehran: World Organisation for Islamic Services.

Ali K. M. M. (2008). Achievements \& Obstacles of Bangladesh takaful Industry. http://mortuzaali.com/articles/43_Achievements_Obstacles_of_Bangladesh_Islamic takaful.pdf. Accessed 8 March, 2018.

Ali, K. M. M. (2012). Bangladesh: The need for takaful regulations. http://www.primeislamilifebd.com/Article/TheNeedTakReg. Accessed 8 March, 2018.

Ali, K. M. M. (2016). Takaful in Bangladesh Seeking a framework for growth. https://www.primeislamilifebd.com/aritcle/takaful/takaful inbangladesh.pdf. Accessed 8

March, 2018.

ARCSCIIB. (2010). Annual Report Central Shariah Council for Islamic Insurance of Bangladesh.

ARCSCIIB. (2011). Annual Report Central Shariah Council for Islamic Insurance of Bangladesh.

ARIIBL. (2012). Annual Report Islamic Insurance Bangladesh Ltd. 
INTERNATIONAL JOURNAL OF ACADEMIC RESEARCH IN BUSINESS AND SOCIAL SCIENCES

Vol. 9, No. 1, Jan, 2019, E-ISSN: 2222-6990 (C) 2019 HRMARS

ARPILIL. (2012). Annual Report Prime Islamic Life Insurance Ltd.

ARTIIL. (2012). Annual Report takaful Islami Insurance Ltd Azad.

Banaga, A., Tomkins, C. R., \& Ray, G. H. (1994). External audit and corporate governance in Islamic banks: A joint practitioner-academic research study. Avebury.

Bank Negara Malaysia. (2010). Shariah Governance Framework for Islamic Financial Institutions (BNM/RH/GL 012-3). Kuala Lumpur: Bank Negara Malaysia.

Chapra, M. U. (1992). Islam and the economic challenge (No. 17). International Institute of Islamic Thought (IIIT).

Chowdhury, S. E. (2014). Financial System in Bangladesh. https://www.scribd.com/doc/29065718/Financial-System-in-Bangladesh. $\quad$ Accessed 8 March, 2018.

Choudury, M. A. \& Hoque, M. Z. (2004). An Advanced Exposition of Islamic Economics and Finance, Edward Mellen Press, New York, NY.

Choudhury, M. A., \& Malik, U. A. (1992). 'Mudarabah', the Profit-sharing System in Islam. In The Foundations of Islamic Political Economy(pp. 147-200). Palgrave Macmillan, London.

Foster, N. H. (2007). Islamic Finance Law as an emergent Legal system. Arab Law Quarterly, 21(2), 170-188.

Ginena, K., \& Hamid, A. (2015). Foundations of Shari'ah governance of Islamic banks. John Wiley \& Sons.

Hasan, Z. (2008). Corporate governance of Islamic financial institutions. In Conference on Malaysian Study of Islam, Lamperter, United Kingdom.

Hasan, Z. (2009). Corporate Governance: Western and Islamic Perspectives. International Review of Business Research Papers, 5(1), 277-293.

Hamza, H. (2013). Sharia governance in Islamic banks: effectiveness and supervision model. International Journal of Islamic and Middle Eastern Finance and Management, 6(3), 226-237. 
INTERNATIONAL JOURNAL OF ACADEMIC RESEARCH IN BUSINESS AND SOCIAL SCIENCES

Vol. 9, No. 1, Jan, 2019, E-ISSN: 2222-6990 (C) 2019 HRMARS

Hassan, M. K., Ullah, M. F. \& Khanam, R. (2017). Shariah Governance Practices in Bangladesh, Chapter in Shariah Governance Systems and Practices in a Globalized World, Edited by Nazim Ali, 2017.

Hosen, S., Islam, M. A., Arshad, M. M., Khan, A. M., \& Alam, M. K. (2018). Talent Management: An Escalating Strategic Focus in Bangladeshi Banking Industry. International Journal of Academic Research in Business and Social Sciences, 8(1), 156-166. DOI: 10.6007/IJARBSS/v8-i1/3801

Islamic Financial Services Board -3. (2006). Guiding Principles on Corporate Governance for Institutions Offering Only Islamic Financial Services (Excluding Islamic Insurance (Takaful)

Institutions and Islamic Mutual Funds, Islamic Financial Services Board, Kuala Lumpur.

Islamic Financial Services Board. (2009). Guiding Principles on Shariah Governance System for Institutions offering Islamic Financial Services, Islamic Financial Services Board.

Kahf, M. (1978). The Islamic Economy: Analytical Study of the Functioning of the Islamic Economic System (Plainfield, Indiana: Muslim Students Association of the United States and Canada. 1978).

Kalil, M.E. (2011). Islamee Banking and Insurance. Merit Fair Prokashon, Dhaka.

Khalid, M. S. A. (2007). Islami Economy and Insurance some Issues. Shiddikiyah Publication, Dhaka.

Khan, H. U. Z. (2010). The effect of corporate governance elements on corporate social responsibility (CSR) reporting: Empirical evidence from private commercial banks of Bangladesh. International Journal of Law and Management, 52(2), 82-109.

Khan, I., Rahman, N. N. B. A., Yusoff, M. Y. Z. B. M., \& Nor, M. R. B. M. (2016). History, problems, and prospects of takaful (Islamic insurance) in Bangladesh. SpringerPlus, 5(1), 785-791.

Mannan, M. A. (1970). Islamic Economics: Theory and practice: A comparative study. Kazi Pubns Inc.

Miah, M. M. R. (1992). The cultural-structural contexts of high fertility in Bangladesh: A sociological analysis. International Review of Modern Sociology, 22 (1), 99-110.

Naqvi, S. N. H. (1981). Ethics and economics: An Islamic synthesis (Vol. 2). islamic Foundation.

Nathan, S., \& Ribière, V. (2007). From knowledge to wisdom: the case of corporate governance in Islamic banking. Vine, 37(4), 471-483. 
INTERNATIONAL JOURNAL OF ACADEMIC RESEARCH IN BUSINESS AND SOCIAL SCIENCES

Vol. 9, No. 1, Jan, 2019, E-ISSN: 2222-6990 (C) 2019 HRMARS

NuHtay, S. N., \& Salman, S. A. (2013). Comparative Analysis on AAOIFI, IFSB and BNM Shari'ah Governance Guidelines. International Journal of Business and Social Science, 4(15), 220-227.

Nienhaus, V. (2007). Governance of Islamic Banks, in: Hassan, M.K./Lewis, M.K. (Hrsg.), Handbook of Islamic Banking, Edward Elgar, Cheltenham (UK) u.a., 128-143.

Sarwar, M. J. (2016). Future Challenge in takaful (Islamic insurance) in Bangladesh. Aust J Sustainable Business Society, 2(1), 69-80.

Schwarcz, D, \& Schwarcz, S. L. (2014). Regulating Systemic risk in insurance. Univ Chicago Law Rev, 81(4), 1569-1640. doi:10.2139/ssrn.2404492.

Siddiqi, M. N. (1978). Some Aspect of the Islamic Economy. Lahore: Islamic Publication.

Taleghani, S. M. (1983). Islam and Ownership (Transl.). Lexington: Mazda Press.

TJCSCIIB. (2012). Takaful Journal of Central Shariah Council for Islamic Insurance of Bangladesh.

Ullah, M. W. (2013). Role of the Shariyah Officer (Muraqib) as Practiced by Prime Islami Life Insurance Ltd., Bangladesh.

Wardhany, N., \& Arshad, S. (2012). The Role of Shariah Board in Islamic Banks: A Case Study of Malaysia, Indonesia, and Brunei Darussalam. In 2nd Isra Colloquium.

Yazid, A. S., Arifin, J., Hussin, M. R., \& Daud, W. N. W. (2012). Determinants of family takaful (Islamic life insurance) demand: a conceptual framework for a Malaysian study. International Journal of Business and Management, 7(6), 115-127. Doi:10.5539/ijbm.v7n6p11. 